ks. Janusz Królikowski

Uniwersytet Papieski Jana Pawła II w Krakowie

DOI: 10.15290/std.2017.03.07

\title{
„STAŁA POKUSA WIARY”. WSPÓŁCZESNE BAEWOCHWALSTWO I JEGO GENEZA
}

\section{"CONSTANT TEMPTATION OF FAITH". CONTEMPORARY IDOLATRY AND ITS ORIGINS}

Looking at some reputedly religious phenomena in today's world we could openly ask whether these phenomena don't fall, in certain cases, into a category of a new kind of idolatry which means replacing God with a creature. It is the world of human sensations and experiences that should be especially taken into consideration, sensations and experiences which are often regarded as religious or which, in some cases, undergo the process of absolutisation, whereas this is only a kind of concentration on oneself or on a particular thing. It has been noticed quite accurately, that modern times can be characterised by a shift "from wooden idols to spiritual idols". Therefore, there is an urgent need for philosophical and theological perspective on this broad sphere of experiences, and for a question whether those experiences create new idols and, by the same token, whether they are idolatrous in character. To answer these questions responsibly and coherently we have to define the origins of idolatry and concurrently find the appropriate criteria which will enable us to evaluate theologically respective phenomena which may appear questionable. This very issue constitutes the subject of this study.

Key words: God, name of God, deity/idol, image worship/idolatry, error, sin, worship, religion, positivism, metaphysics, culture. 
Katechizm Kościoła katolickiego z głęboką znajomością psychologii i wrażliwości religijnej człowieka stwierdza:

Bałwochwalstwo nie odnosi się tylko do fałszywych kultów pogańskich. Pozostaje stałą pokusą wiary. Polega na ubóstwieniu tego, co nie jest Bogiem. Ma ono miejsce zawsze wtedy, gdy człowiek czci i wielbi stworzenie zamiast Boga, bez względu na to, czy chodzi o innych bogów czy o demony (np. satanizm), o władzę, o przyjemność, rasę, przodków, państwo, pieniądze itd. ${ }^{1}$

Patrząc na wiele dzisiejszych zjawisk, którym nadaje się miano religijnych, trzeba otwarcie postawić sobie pytanie, czy w niektórych przypadkach nie mamy do czynienia z jakąś postacią bałwochwalstwa (idolatrii), czyli stawiania jakiegoś stworzenia w miejsce Boga. Należy zwłaszcza zwrócić uwagę na świat ludzkich doznań, które często uważa się za religijne bądź też w niektórych sytuacjach dokonuje się ich absolutyzacji, a są one tylko jakimś skoncentrowaniem się na sobie bądź na jakiejś rzeczy. Z takim zjawiskiem mamy np. do czynienia w „spoczynku w Duchu Świętym”, będącym w zasadniczej mierze absolutyzacją ludzkich doznań, bardzo bliskich herezji messalianizmu, a nawet $z$ nią tożsamych ${ }^{3}$. Trafnie zwrócono uwagę, że w czasach nowożytnych nastąpiło przejście „od bożków drewnianych do bożków ducha"

Pojawia się więc pilna potrzeba filozoficzno-teologicznego spojrzenia na tę rozległą sferę doświadczeń i otwartego zapytania się, czy nie tworzą one nowych idoli, a tym samym czy nie mają charakteru bałwochwalczego. Aby na to pytanie spójnie odpowiedzieć, trzeba przede wszystkim zidentyfikować genezę bałwochwalstwa, a dzięki temu uzyska się odpowiednie kryteria, pozwalające ocenić teologicznie poszczególne zjawiska, które mogą budzić nasze wątpliwości ${ }^{5}$.

$1 \quad$ Katechizm Kościoła katolickiego, Poznań 2002, nr 2113.

2 Por. W. Cyran, Spoczynek w Duchu Świętym. Refleksja teologiczna i świadectwa, Częstochowa 2010.

3 Kongregacja Nauki Wiary, List Orationis formas, 9, [w:] W trosce opetnię wiary. Dokumenty Kongregacji Nauki Wiary. Dokumenty Kongregacji Nauki Wiary 1966-1994, J. Królikowski, Z. Zimowski (red.), Tarnów 2010, s. 412.

$4 \quad$ Por. R. Dekoninck, Des idoles de bois aux idoles de l'esprit. Les métamorphoses de l'idolâtrie dans l'imaginaire moderne, „Revue théologique de Louvain” (2004) 35, s. 203-216.

$5 \quad$ Warto mieć na uwadze, że w wielu kręgach teologicznych zagadnienia tego typu są już podejmowane i analizowane z wielu punktów widzenia. Por. Autour de l'idolâtrie. Figures actuelles de pouvoir et de domination, B. Van Meenen (red.), Bruxelles 2003; L'idole dans l'imaginaire occidental, R. Dekoninck, M. Watthee-Delmotte (red.), Paris 2005; L. Alici, Cielo di plastica. L'eclisse dell'infinito nell'epoca delle idolatrie, Cinisello Balsamo 2009. 


\section{Źródła bałwochwalstwa}

\section{Błąd}

Mówiąc o idolach, w punkcie wyjścia musimy uwzględnić relację, która łączy człowieka z Bogiem na poziomie podstawowego poznania, jakie o Nim posiadamy. Uznajemy, że oprócz światła Objawienie, przez które Bóg mówi nam, kim On jest, rozum ludzki może dojść do pewnego poznania Stwórcy. Droga prowadząca do tego poznania jest bardzo wymagająca i trudna, obarczona rozmaitymi trudnościami i przeszkodami, zwłaszcza ludzką ograniczonością intelektualną i moralną, nawet jeśli należy władze rozumu i woli uznać za wyjątkowe. Historia myśli ludzkiej jest rzeczywiście bardzo długa w tym względzie, ale jest ona zarazem bardzo uboga, jeśli chodzi o faktycznie osiągnięte rezultaty. Ilustruje ona bardzo wymownie fakt, że natura ludzka zraniona przez grzech jest daleka od pełnego i efektywnego wykorzystania wszystkich swoich wrodzonych możliwości. Tam, gdzie umysł ludzki doszedł do jakiegoś poznania Boga, to przy bliższej analizie efektów tego poznania, okazuje się jednak, że ono jest obciążone wieloma błędami i niedopowiedzeniami. Oczywiście, błąd w odniesieniu do Boga nie czyni $z$ tego błędu w sposób konieczny idola. To, co wielcy filozofowie greccy czy mędrcy indyjscy mogli powiedzieć o Bogu, nie jest odrzucane przez filozofię chrześcijańską, ale zostaje poddane oczyszczeniu i udoskonaleniu. Błędy poznawcze dotyczące Boga nie są sobie równe. Niektórych z nich można było uniknąć, a innych nie. O bałwochwalstwie można mówić w takich przypadkach, w których błąd jest zawiniony przez człowieka. Można - na przykład - nie znać jakiegoś przymiotu Boga lub nie uznawać tajemnicy stworzenia bez popadania w bałwochwalstwo, ale nie można go uniknąć, jeśli dokonywałoby się wyeliminowania całkowicie szczególnej i niedostępnej dla człowieka wyjątkowości Najwyższego.

Jeżeli chodzi o poznanie nadprzyrodzone należy zauważyć, że w Starym Testamencie objawienie prawdziwego Boga, który jest przedmiotem wiary nadprzyrodzonej, dokonało się stopniowo. Można mówić o „prawdziwej pedagogii Bożej” w tym względzie ${ }^{6}$. W objawieniu tym miało miejsce szerokie wykorzystanie metafor i antropomorfizmów oraz odwołanie się do języka symbolicznego ${ }^{7}$. Jest niewątpliwie znaczące, że nie ucierpiało na tym, jeszcze bardzo niedoskonałe, poznanie Boga. Wykorzystanie obrazów nie zakłada

\footnotetext{
6 Por. II Sobór Watykański, Konst. Dei Verbum, 15.

7 Por. P. Grelot, La langage symbolique dans la Bible, Paris 2001.
} 
w sposób konieczny bałwochwalstwa. Współcześni apologeci chrześcijańscy idą zbyt daleko, gdy przesadnie przypisują dzisiejszemu ateizmowi moc oczyszczającą w stosunku do naszych niedoskonałych przedstawień Boga i do naszego języka teologicznego. Biblia jednoznacznie poświadcza, że najbardziej autentyczna wiara nadprzyrodzona może posługiwać się najprostszymi metaforami; wcale nie potrzebuje wyszukanego języka i subtelnych przedstawień. Jeśli jakaś metafora oświeca ducha ludzkiego, zbliżając go do prawdy, przestaje być już tylko metaforą i staje się bezpośrednim i właściwym przedstawieniem przedmiotu. Wykorzystanie wyobraźni nie zaciemnia rozumu, oczywiście pod warunkiem, że zostaje utrzymane na właściwym dla niej poziomie i wykorzystane we właściwym dla niej zakresie. Czym innym jest wykorzystanie obrazu przez rozum, a czym innym sprowadzenie myślenia do wyobraźni. Święty Tomasz z Akwinu, zaznacza w odniesieniu do starożytnych filozofów, którzy przypisywali Bogu naturą cielesną, że źródłem ich błędu była chęć wyobrażenia sobie tego, co dotyczy Boga, gdy tymczasem wyobraźnia dostarcza obrazów odnoszących się tylko do dziedziny rzeczy cielesnych $^{8}$. Przyczynę bałwochwalstwa, za Księga Mądrości, upatruje on w naturalnej przyjemności, którą człowiek znajduje w tworzonych przez siebie wyobrażeniach. Rzeczywistości duchowe przekraczają jednak zdolności wobrażeniowe człowieka. Wolna myśl, która posługuje się wyobraźnią, może używać metafor, byle była świadoma ich ograniczoności i zakresu ich możliwego wykorzystania. Jeśli więc ateizm posiada jakąś moc oczyszczającą, to nie $z$ tej racji, że tradycyjne przedstawienia Boga są pozbawione wartości, ale $z$ tej, że te przedstawienia - w takiej mierze, w jakiej są w jakimś stopniu obciążone antropomorfizmami - nie są dla wiary dość głębokie, by ludzki duch mógł je uznać za narzędzia całkowicie adekwatne i uprawnione do wykorzystania w swoim myśleniu o Bogu. Dobrze opracowana lekcja natury i metody teologii są jednak wystarczającymi narzędziami, by takiego oczyszczenie dokonywać w jeszcze większym stopniu.

Pozostaje więc stwierdzić w tym miejscu, że bałwochwalstwo nie wyjaśnia się tylko i wyłącznie na poziomie poznawczym. Zakłada ono oczywiście błąd w stosunku do Boga i niekiedy mamy do czynienia z bałwochwalstwem typu poznawczego, ale nie można go sprowadzić tylko do tego rodzaju błędu. Byłoby to uproszczenie, a poza tym ulegałaby obniżeniu odpowiedzialność moralna, biorąc pod uwagę ograniczoność ludzkiego poznania w kwestiach religijnych.

8 Por. Tomasz z Akwinu, Summa contra gentiles I, 20. 


\section{Nienawišć Boga}

Bóg, który jest światłem ducha ludzkiego, jest celem ostatecznym człowieka. Z tej racji jest przedmiotem woli - pierwszej miłości, która polaryzuje i ukierunkowuje wszystkie ludzkie wybory. Takie podstawowe postawienie sprawy, domaga się zarazem pytania o to, co dzieje się wtedy, gdy przez grzech śmiertelny człowiek odwraca się od Boga? Zastępuje on Boga innym stworzeniem, czyniąc je swoim celem ostatecznym. Analiza grzechu śmiertelnego dostarcza ważnych wyjaśnień dotyczących związków, które mogą zachodzić między ateizmem i bałwochwalstwem. Grzeszną wolą stworzenie odrzuca Boga. Tymczasem grzesznik nie zna nieuporządkowanego i degradującego charakteru tej miłości. Jego sumienie nie przestaje go napominać, że jedynie prawdziwy Bóg ma prawo do miłości, angażującej całe ludzkie przeznaczenie. Stworzenie, kiedy zastępuje się nim Boga, zajmuje nieprzysługujące mu miejsce. Im bardziej grzesznik przywiązuje się do tego stworzenia, tym bardziej zanika w nim pamięć o Bogu, a nawet okazuje się uciążliwa i przykra. Bóg staje się intruzem, który przeszkadza w radosnym i spokojnym korzystaniu ze stworzenia. Właśnie dlatego, jeśli trwa grzech śmiertelny i coraz bardziej się utrwala, wywołuje nienawiść w stosunku do Boga, gdyż staje się On „konkurentem” dla stworzonego przez grzesznika „boga”, który został obrany za cel ostateczny. Gniew w stosunku do prawdziwego Boga, gdy zostanie mu nadana skrajnie wysoka ranga, może nawet wywołać absurdalne pragnienie zniszczenia Boga - bogobójstwo. Wskazał na to bardzo trafnie już kardynał Kajetan w komentarzu do Sumy teologii św. Tomasza9.

Nienawiść do Boga połączona z chęcią zniszczenia Go nie jest obca pewnym formom ateizmu współczesnego, którym nadajemy miano „ateizmu wojującego". Zwłaszcza pycha prometejska prowadzi do ateizmu, który jest przede wszystkim antyteizmem. Źródeł takiego antyteizmu nie należy upatrywać w błądzeniu rozumu, ale głownie w dramatach duchowych, których doświadcza człowiek. Ponieważ nie potrafi z nimi się uporać, dlatego zwraca się przeciw Bogu i przeciw religii. Do takiego wniosku doszedł już św. Augustyn, co wyraził w swojej doktrynie „dwóch państw”: „Dwie miłości [...] powołały dwa państwa: miłość własna, posunięta aż do pogardy Boga, powołała państwo ziemskie; miłość Boga zaś posunięta aż do pogardy sobą, powołała państwo niebieskie"10.

\footnotetext{
$9 \quad$ Por. Kajetan, In Summa theologiae II-II q. 34 a. 1 ad 2.

10 Augustyn, O państwie Bożym [14, 28], tł. W. Kornatowski, t. 2, Warszawa 1977, s. 162.
} 
Ten rodzaj antyteizmu, który wypowiada bezpardonową wojnę Bogu właściwie będącą buntem przeciw prawdziwemu Bogu - na mocy dialektyki, która zawarta jest w grzechu pychy, stanowiącej jego źródło, bezkrytycznie stawia bożka w miejsce Boga, którego chce się pozbyć. Tego rodzaju bunt przeciw Bogu w dużej części inspiruje twórczość artystyczną i refleksję filozoficzną w XIX i XX wieku. Najbardziej wymowne i wpływowe wyrazy tego faktu spotykamy w dziedzinie doświadczenia poetyckiego i w dziedzinie ideologii politycznych. Jest niewątpliwie znaczące, że w większości przypadków to „ja”, które detronizuje Boga, nie zajmuje Jego miejsca. Ten podmiot, który dokonuje detronizacji Boga, doświadcza rozmaitych iluzji, formułuje niezliczone pretensje, chce przekroczyć granice „tego, co ludzkie”, oczekuje na pojawienie się jakiegoś „super-człowieka” rozumianego, bądź w sposób indywidualny, bądź w sposób kolektywny. Bunt prometejski prowadzi do zastąpienia starożytnych mitów nowymi idolami.

Bóg, będący najwyższym i suwerennym Dobrem, zostaje zastąpiony przez jakieś inne dobra. Możemy wówczas powiedzieć, że każde dobro stworzone, zajmujące miejsce Boga w sercu grzesznika, staje się idolem. W tej perspektywie należy rozumieć wypowiedź św. Pawła o obżarstwie, które staje się bałwochwalstwem (por. Ef 5, 5; Kol 3, 5). Epopeja romantyczna pychy prometejskiej zasługuje na miano szczególnego typu bałwochwalstwa, gdy uwzględni się kierujące nią dążenia. W tym nurcie człowiek zbuntowany nie zadowala się trwaniem przy obranych założeniach, ale usiłuje za wszelką cenę zrewidować całość swojej koncepcji świata: nie wystarczy mu już wyrzucenie Boga z woli, ale usiłuje go także wyeliminować z pamięci i oczyścić rozum z choćby najmniejszych Jego śladów. W nowej konstrukcji ideologicznej, bardzo zatroskanej o uniemożliwienie Bogu jakiegokolwiek powrotu do świata i człowieka, zostają wprowadzone takie struktury myślowe i mechanizmy kulturowe, które odgórnie nakładają się na zbuntowane „ja”, nie utożsamiając się z nim. Co więcej, łącząc się z wyobrażeniami i elementami mitycznymi, wywierają na człowieka presję prowadzącą do składania ofiary z siebie. Twory myślowe człowieka stają się dla niego wyzwaniem, znajduje się on przed własnym obrazem, poddając się jego tyranii.

\section{Grzech przeciw cnocie religijności}

Zwrócenie uwagi na miłość, która kieruje człowieka do jego celu, pozwala nam na dokonanie pewnego sprecyzowania. Otóż, idol pojawia się i działa w ramach przeżywanej relacji, w dynamizmie perwersyjnej miłości. 
Zastępuje ona prawdziwego Boga, koncentrując na sobie miłość, która jest $\mathrm{Mu}$ należna. Trzeba ponadto podkreślić jeszcze inny element. Zajmując miejsce prawdziwego Boga, idol skierowuje na siebie kult boski. Właściwie biorąc, to kontekst religijny i kultyczny ukazuje w pełni, czym jest idol, a tym samym pozwala nam zidentyfikować perwersję bałwochwalczą, która dotyka równocześnie rozum i wolę.

Cnota religijności uzdalnia człowieka do oddawania Bogu tego, co jest mu należne. Ponieważ jednak Bogu należy się absolutnie wszystko, człowiek nie jest w stanie tego uczynić w takim stopniu; otrzymuje od Niego nieskończenie więcej niż może Mu dać. Religia opiera się na sprawiedliwości, przy czym człowiek nie może oddać Bogu tego, co mu się ze sprawiedliwości należy. Religijność umożliwia jednak człowiekowi oddanie Bogu tego, co jest po ludzku możliwe za pośrednictwem pewnych aktów, które są wewnętrznymi lub zewnętrznymi aktami kultu.

Sprawiedliwość oznacza pewną odpowiednią „miarę”, która - chociaż nie ma charakteru arbitralnego - opierając się na naturze rzeczywistości, odnosi się do prawdy. Kult należny Bogu czerpie swoją właściwą miarę z wzniosłości Bożej; jego miarą jest to, że kieruje się do prawdziwego Boga w Jego szczególnej i nieprzekazywalnej nikomu transcendencji. Akty cnoty religijności zwracają się w sposób właściwy do Boga, ponieważ jedynie Bóg jest Bogiem. Perwersja bałwochwalcza jest tak bardzo dogłębna i zgubna, gdyż kwestionuje tę podstawową prawdę, redukując Boga do rangi stworzenia. Stanowi ona skrajną głupotę i zarozumiałość, ponieważ ośmiela się przypisać „kamieniom i drewnu”, a więc przedmiotom materialnym, ,niekomunikowalne Imię" (Mdr 14, 21). Sprzeciwia się więc szacunkowi dla Wszechmocnego. W wyniku takiego postępowania człowiek odchodzi od prawdy i pogrąża się w nocy kłamstwa. Święty Tomasz podkreśla, że człowiek okazuje kult Bogu nie $z$ tej racji, żeby On go potrzebował, ale „aby utwierdzić w nas, właśnie przez znaki widzialne, prawdziwy pogląd o Bogu"11. W czwartej prefacji zwykłej znajdujemy liturgiczne przedłużenie tego przekonania, gdy modlimy się: „Nasze hymny pochwalne niczego Tobie nie dodają, ale się przyczyniają do naszego Zbawienia" (nr 39). Trzeba przypomnieć w tym miejscu także ważne zdanie św. Pawła z Listu do Rzymian: „Prawdę Bożą przemienili oni w kłamstwo i stworzeniu oddawali cześć, i służyli jemu, zamiast służyć Stwórcy, który jest błogosławiony na wieki. Amen" (Rz 1, 25).

O swoich własnych siłach, człowiek może dojść do poznania Boga tylko za cenę niezmiernych wysiłków. Skłonność do grzechu bez przerwy wywiera

11 Tomasz z Akwinu, Summa contra gentiles III, 120. 
presję na wolę, prowadząc ją do opowiedzenia się po stronie stworzeń. Nie należy więc się dziwić, że bałwochwalstwo nieustannie nęka człowieka w ciągu jego dziejów. Charakterystyczny dla naszych czasów jest fakt, że rozmaite formy perwersji bałwochwalczej nie są jasno określane i nie da się ich łatwo zidentyfikować, ale przybierają formy subtelne i często zamaskowane. Rozwijają się koncepcje życia czysto świeckiego i laickiego. Mentalność naukowa wnosi znaczący wkład w rodzenie się i utrwalanie laicyzmu. Duch naukowy jest utożsamiany z duchem rozumu i może wydawać się, że odniesienie do rozum wystarczy, aby wyeliminować „byty wyobrażeniowe”, którymi są idole. Rzeczywiście, tryumf rozumu w dziedzinie poznania naukowego i realizacji technicznych wyznacza równocześnie schyłek rozumu metafizycznego. Doktryna pozytywistyczna ma w tym względzie rangę symptomatyczną rozum naukowy dąży do wyzwolenia się od rozumu filozoficznego jak z jakichś pęt. Duch naukowy stanowi część dziedzictwa, które zawdzięczamy kulturze greckiej. Tymczasem klimat kulturowy uległ głębokim zmianom od czasów starożytnych. W starożytnej Grecji ciekawość naukowa rozwijała się w kontekście odważnych poszukiwań metafizycznych, podczas gdy współczesnym zdobyczom świata materialnego towarzyszy abdykacja rozumu wobec głębszych problemów. Dochodzi do tego - u samych filozofów - deklaracja niezdolności rozumu do podjęcia istotnych problemów dotyczących człowieka. Ten kryzys dotyka także myślicieli chrześcijańskich, którzy chronią się w niby spokojnym domu fideizmu.

Fakt abdykacji rozumu metafizycznego w cywilizacji naukowo-technicznej nie może sprawić, że zniknie on z naszego pola widzenia. Nie można pozwolić na to, by człowiek utwierdził się w przekonaniu, że skoro jego rozum zdołał osiągnąć pewne poznanie umożliwiające człowiekowi panowanie w świecie materialnym, to tym samym kontroluje już całość problemów ludzkich. Rozum wyspecjalizował się tylko w jednym kierunku, rezygnując z obecności na rozległych obszarach rzeczywistości, a tym samym zapomniał o swoim powołaniu uniwersalnym, to znaczy o tym, że stale ma „poszerzać horyzonty racjonalności”, jak wielokrotnie podkreślał papież Benedykt XVI w swoim nauczaniu ${ }^{12}$. Rezygnacja z uniwersalizmu uniemożliwia człowiekowi właściwe usytuowanie się w świecie oraz sprawia, że w dziedziny życia, które zostają zapomniane przez rozum, wchodzą rozmaite mity. Skrajny racjonalizm i mentalność mitologiczna współistnieją ze sobą i mogą na siebie wpływać - mitologia może stymulować rozwój, ale zawsze zwraca

12 Por. L. Leuzzi, Allargare gli orizzonti della razionalità. I discorsi per l'Università di Benedetto XVI, Milano 2008. 
się przeciw człowiekowi. Francisco Goya trafnie zauważył: „Gdy rozum śpi, budzą się demony”. Rozum rezygnujący ze swego najwyższego powołania, którym jest poszukiwanie pierwszych prawd, staje się promotorem mitów i idoli. W tym należy upatrywać szczególną wymowę encykliki Fides et ratio Papieża Jana Pawła II, w której zachęca do odnowy filozofii i do korzystania z niej zarówno w Kościele, jak i we współczesnej kulturze. Niestety, jest to dokument, który pozostaje jednym z bardziej zapomnianych „Papieża Filozofa” jak napisano w „New York Times” nazajutrz po ogłoszeniu encykliki o wierze i rozumie.

\section{Filozofia i bałwochwalstwo}

Dotychczasowe rozważania o ogólnym charakterze zwracają uwagę, że większości przypadków odrzucenia Boga towarzyszymy zjawisko, które możemy nazwać „wymianą wartości”. Ateizm „czysty”, który czyniłby człowieka wyłącznie samotnym, jest dość rzadki. Ateizm na ogól, w takiej czy innej formie, odwołuje się do idoli. Idole jawią się w ten sposób jako twory zastępujące Boga i następuje wypaczenie kultu należnego tylko Bogu

\section{Rozdzielenie między Bogiem i religią}

Powrót do idoli charakterystycznych dla nowych ideologii został w sposób szczególny przygotowany przez ten kierunek myślowy, który można umiejscowić na początku XIX wieku. Może on być schematycznie nakreślony jako odpowiedź na ten cios, który na początku wydawał się śmiertelny, a który filozofia Kanta miała zadać metafizyce klasycznej. Wydawało się, że zostało na trwałe określone suwerenne panowanie rozumu w dziedzinie, którą tworzą elementy i formy wyrazu świata materialnego, opisywane przez nauki matematyczno-fizyczne. Rozum jest niezdolny do odkrycia jakiegoś śladu Boga w świecie, dlatego ma milczeć na Jego temat. Kant, za którym poszli inni myśliciele, drastycznie zakwestionował możliwość Objawienia ${ }^{13}$.

Czy zatem chrześcijaństwo zostało skazane na zagładę? Wielu w to uwierzyło, a wśród nich młody pastor berliński Schleiermacher, który w sposób dość systematyczny wyłożył swoje wątpliwości w tej materii. W słynnych Mowach o religii pozostawił nam rezultaty swoich przemyśleń ${ }^{14}$. Zaakceptował wizję Kanta odnośnie do rozumu, filozofii i moralności. Religia jako taka jest według

13 Por. A. Szwed, Rozum wobec chrześcijańskiego objawienia. Kant, Hegel, Kierkegaard, Kęty 2011.

14 Por. F. Schleiermacher, Mowy o religii do wyksztatconych spośród tych, którzy nia gardza, tł. J. Prokopiuk, Kraków 1995. 
niego zdolnością duchową sui generis, niezależną od wiedzy i sumienia moralnego, dlatego jest ona przestrzenią uczucia - uczucia przynależności człowieka do całości wszechświata. Schleiermacher sprecyzuje później, że jest to uczucie „zależności”. Takie uczucie, oddzielone od rozumu, nie może być wydzielone za pośrednictwem jego przedmiotu, który nie podlega określeniu intelektualnemu. Przedmioty uczucia religijnego są formami dowolnymi i przygodnymi, za pośrednictwem których to uczucie wyraża swoją spontaniczność. Schleiermacher posuwa się do twierdzenia, że nawet sam Bóg nie jest konieczny dla „religii”, gdyż jest On tylko jednym z wielu „przedstawień”, które przybiera uczucie. Co więcej, nie ma istotnej różnicy między politeizmem i monoteizmem - są to równouprawnione postacie religii. Sam Schleiermacher zwracał się w kierunku politeizmu i nigdy nie opowiedział się za osobową naturą Boga.

W konsekwencji religia nie różni się niczym od postawy podmiotu religijnego, a tym samym traci wszelkie miary obiektywne. Nie ma więc możliwości rozróżnienia między prawdziwym Bogiem i idolem, ponieważ na poziomie uczuć nie ma niczego, co pozwalałoby określić taką różnicę. Będzie się więc mówić o religii i jej różnych formach historycznych, nie stawiając przy tym problemu religii prawdziwej i fałszywej. Co więcej, można powiedzieć za Heglem - który wprawdzie krytykuje Schleiermachera, ale zgadza się z nim co do istoty jego poglądu - że religia ewoluowała w biegu dziejów i że chrześcijaństwo jest jej wyższym stopniem. Nie chodzi jednak tutaj o przeciwstawienie między prawdą i idolami.

Myśl Schleiermachera wywierała i nadal wywiera wpływ w spojrzeniu na religię. Liczne ślady tego wpływu można znaleźć np. w pismach Rudolfa Bultmanna. Inspirowała ona i nadal inspiruje historię religii, która - sytuując się zasadniczo na poziomie analizy opisowej - nie formułuje sądów wartościujących na temat natury ich przedmiotu: wszystkie religie są jednakowo uprawnione, a może nawet równoważne, ponieważ są tylko zróżnicowanym wyrażeniem tej samej postawy religijnej. Problem prawdy o Bogu jest uważany za drugorzędny, jeśli nie zupełnie zbyteczny. Człowiek religijny jest określany przez jego uczucie odnośnie do tego, co Boskie, bez jasnego sprecyzowania, czym jest to, co Boskie. Postawa religijna nie jest już mierzona prawdą o Bogu. Jeśli ma ona jakąś miarę, to trzeba jej szukać w immanencji podmiotu religijnego. Kult w sobie czy obrzęd, gorliwość emocji abstrahują faktycznie od bytu czy przedmiotu, do którego są adresowane.

Co oznacza miara dostarczana przez immanencję podmiotu, jeśli nie odwołanie się do kryterium użyteczności? Gdy potem pojawi się Feuerbach, to nie zrobi niczego więcej niż zaproponował Schleiermacher. Stwierdzi on, że „przedstawienie” Boga transcendentnego, o którym już wiemy, że jest tylko „przedstawieniem", jest po prostu szkodliwe dla człowieka. Feuerbach rozciągnie to 
przekonanie na zmysł sacrum. Cześć, zamiast zwracać się do transcendentnej fikcji, powinna kierować się do „Ludzkości”, która jest wyrażeniem immanencji. „Ludzkość” - to nowy idol, który zwraca do siebie kult zarezerwowany „niekomunikowalnemu Imieniu”. Człowiek przebóstwiony, zależnie od okoliczności historycznych, będzie mógł dowolnie zmieniać to imię. Odnajdujemy je potem w Proletariacie lub Historii u marksistów, w Rasie u nazistów, w Państwie u faszystów i nacjonalistów. Już państwo Hegla jest pewnym rodzajem takiego idola. Te mity i ich analogie poprzedzają koncepcję czysto immanentną i służą do walki z ideą transcendencji. Myśliciele sytuujący się w tym nurcie byli na ogół wrogo nastawieni do chrześcijaństwa. Zdarzali się wprawdzie myśliciele, którzy wychodzili z założeń filozofii immanentnej i bronili chrześcijaństwa jako religii użytecznej dla ludu, ale nie uznawali jej prawdziwości. Przykładem takiego myśliciela może być Benedetto Croce ze swoją bluźnierczą koncepcją „starego boga"15.

\section{Pozytywizm Augusta Comte’a}

Postawa myślowa, której archetypicznym przykładem jest Schleiermacher, wprowadza dokładny rozdział między zmysłem sacrum (tego, co Boskie) i wymaganiami prawdy. W takim ujęciu problem sytuuje się na poziomie czystego pragmatyzmu, a nie na poziomie prawdy. To, co Boskie, zostaje zredukowane do ludzkiej lub społecznej potrzeby tego, co Boskie. Za taką opcją opowiedział się już Jean-Jacques Rousseau w Umowie społecznej. W takim ujęciu religia jest oceniana i rozpatrywana wyłącznie w oparciu o kryteria polityczne. Robespierre wprowadzając kult Bytu najwyższego okazał się wiernym uczniem Rousseau. Jak w starożytnym pogaństwie, religia nabiera w tym ujęciu charakteru państwowego i podlega kompetencji władcy.

Robespierre ze swoimi działaniami sytuuje się jeszcze na poziomie deizmu. W XIX wieku potrzeba tego, co Boskie, stała się jednak bardziej dwuznaczna, gdy została sprowadzona do potrzeby kultu - czci. Stanowisko kategorycznego ateisty, jakim był August Comte, jest bardzo charakterystyczne w tym względzie. W ramach myśli pozytywistycznej, unikającej wszelkiego odniesienia do kwestii metafizycznych, Comte opracował w najmniejszych detalach kult Wielkiego Bytu, czyli Ludzkości. Program Comte'a opiera się na założeniach, które stały się typowe dla czasów nowożytnych. Najpierw radykalny ateizm, który jest antychrześcijaństwem. Za nim idzie wprowadzenie kultu mającego cele czysto polityczne, ponieważ - wraz z odrzuceniem prawdziwego Boga - dochodzi się do tego, że człowiek adoruje tylko siebie. Wprowadzenie nowego kultu nie może być interpretowane tylko jako wynik wyrachowania politycznego. Comte 
jest równocześnie ofiarą samomistyfikacji i arcykapłanem nowej religii wpada w niekontrolowany determinizm. Kult, który za pośrednictwem postaci Clotilde de Vaux Comte oddaje Kobiecie, oznacza w rzeczywistości, że sentymentalizm i uczuciowość zyskują prawo do absolutnej niezależności odartej ze świętości i niewinności. W tym względzie pozytywizm odrzucił teologię romantyczną Schleiermachera. Religia wyzwala się od Boga; uczucie jest ponad Bogiem. Uczucie nie może jednak stać się treścią: człowiek stwarza więc swoich bogów. Inaczej mówiąc, człowiek dobrowolnie akceptuje bycie twórcą idoli.

\section{Skrajności bałwochwalcze w filozofii}

Jak ateizm i bałwochwalstwo nie łączą się ze sobą na zasadzie konieczności, tak również nie wykluczają się wzajemnie. Idole rodzą się w miejsce tego, co Boskie, gdy zostaje pozbawione prawdy. Odrzucenie prawdziwego Boga pociąga za sobą negację całego prawdziwego poznania Boga. Kantyzm, który wywołał reakcję Schleiermachera, wywarł jeszcze wpływ w innym sensie. Nauczanie metafizyki dotyczącej Boga i metafizyki Objawienia stanowią już tylko „przedstawienia” pozbawione obiektywnej podstawy. Myślenie o Bogu oznacza utworzenie sobie obrazu - uformowanie go w kategoriach czysto ludzkich, a więc uczynienie sobie idola. Bóg - zakładając, że istnieje - nie jest przedmiotem poznania prawdziwościowego. Utożsamia się w ten sposób niedoskonałość naszego poznania, jego nieadekwatność, z błędem. O Bogu nie można powiedzieć niczego, co byłoby prawdziwe, w związku z czym sam dogmat chrześcijański ma charakter bałwochwalczy.

Na bazie błędnej koncepcji poznania przyjętej w kantyzmie, Heidegger uznał zdanie Nietzschego: „Bóg umarl” za wyrażenie podstawowego dążenia filozofii zachodniej, która usiłuje być „pogromczynią idoli” ${ }^{6}$. Myśl powinna bez przerwy rozbijać koncepcje skończone rozumu fabrykującego idole. Wszystkie słowa o Bogu, a więc także słowa, które Bóg adresuje do człowieka, mają charakter bałwochwalczy. Właściwie do takich wniosków prowadzą stwierdzenia Heideggera. Inspirując się językiem mistyków, ale nadając mu znaczenie, które jest mu obce, wydaje się on insynuować, że każde podejście do Absolutu na poziomie filozoficznym zakłada pustkę rozumu i całkowity adogmatyzm. Taka optyka, która przywołuje założenia obecne w religiach Wschodu, nie jest pozbawiona zgubnych zasad. W takiej jednak mierze, w jakiej taka optyka zgadza się w punkcie wyjście, że poznanie ludzkie jest niezdolne sięgnąć do prawdy metafizycznej, sytuuje się na antypodach stwierdzeń biblijnych mówiących o transcendencji prawdziwego Boga. Kluczowe znaczenie w tej kwestii posiada Księga Hioba, co jednoznacznie wykazał św. Tomasz z Akwinu w komentarzu do niej. Na mocy

16 Por. M. Heidegger, Nietzsche, tt. B. Baran, t. 2, Warszawa 1999, s. 34-36. 
wrodzonej fatalności rozum ludzi wytworzył mity i idole. Wydaje się więc, że człowiek nie może żyć bez idoli w takiej mierze, w jakiej nie może pozbyć się rozumu. W konsekwencji dążenie do otwarcia jednostronnie apofatycznego dostępu do Boga narażone jest na niebezpieczeństwo tolerowania fałszywych bogów, a w skrajnym przypadku także na ich aprobatę. Adogmatyzm łączy się $z$ synkretyzmem, który posiada wiele wspólnego z myślą indyjską.

\section{Nadużywanie imienia Bożego}

Zarzut podnoszony pod adresem chrześcijańskiego poznania Boga, że ma charakter bałwochwalczy jest oczywiście obraźliwe i zawiera wiele dwuznaczności. Nie można jednak nie zauważyć także złych skutków powodowanych przez tych, który - praktycznie lub teoretycznie - myślą i mówią banalnie o Bogu i pomniejszają Jego transcendencję. Mówi się np. o Bogu w świecie, utożsamiając Go z prawami natury; nakłada się na Boga, jako dekrety Jego woli i wyrażenia Jego mądrości, najgorsze niegodziwości; włącza się Jego oddziaływanie w przyczyny i działania, które są mu całkowicie obce. Są to błędy, które mają potem poważne konsekwencje w odniesieniu do wiary i wyobraźni religijnej zarówno dzieci i młodzieży, jak i dorosłych, ponieważ kształtują fałszywy obraz Boga.

Zwłaszcza rozmaite nieszczęścia, które ludzie w najbardziej kontrowersyjny sposób łączą z imieniem Boga skłaniają do bałwochwalstwa, ponieważ nie wyrażają szacunku należnego Najwyższemu. W takim przypadku Opatrzność Boża zostaje sprawdzona do rangi bezdusznego i fatalistycznego przeznaczenia, a pod imieniem prawdziwego Boga adoruje się fałszywych bożków pogańskich, a nawet samego „księcia tego świata”. Poważna odpowiedzialność historyczna spada na tych, którzy mówili i mówią o Bogu w sposób banalny, niski i ezoteryczny. Niestety, taki sposób mówienia często jest obecny w tzw. rekolekcjach ewangelizacyjnych, połączonych ze składaniem rozmaitych, często najbardziej dziwnych świadectw. Tego rodzaju nadużycia, a nawet karykatury mogą prowadzić tylko do bluźnierstwa i bezbożności, nawet jeśli na początku bywają interesujące.

\section{Destrukcyjna siła bałwochwalstwa}

Pismo Święte uczy nas czerpać z mądrości prawdziwego Boga, którą nam objawił jako miarę mądrości ludzkiej. Ten, kto adoruje prawdziwego Boga, zachowuje także prawo moralne; swoją wiernością okazywaną temu prawu zaświadcza, że on sam jest w prawdzie. Przeciwnie, ten, kto adoruje fałszywych bogów, oddając się niegodziwym praktykom, poważnie rani swego ducha. 
Księgi prorockie bardzo mocno podkreślają tę prawidłowość ${ }^{17}$. Obecność grzechu bałwochwalstwa w naszym świecie jest silnie związana z głębokim nieuporządkowaniem postaw etycznych. Analiza egzystencjalna postaw narzucanych przez wylansowane postacie wspólczesnych przewodników kulturowych (artystów, celebrytów, sportowców itd.) jest w tym względzie bardzo pouczająca. Dla wzmocnienia swojego oddziaływania niejednokrotnie odwołują się oni do działań i zachowań naśladujących postawy religijne. Także dzięki tej manipulacji stają się oni niejednokrotnie wiąząacym punktem odniesienia dla dokonywanych wyborów i przyjmowanych postaw.

Warto zwrócić w tym miejscu uwagę na akty ofiar z pewną hojnością składane dzisiaj szatanowi, przede wszystkim w ramach aberracji satanistycznych. Gdy adoracja nie kieruje się już do Tego, który jest światłem, składana ofiara staje się samookaleczeniem. Złożenie ofiary Bogu, najwyższemu Panu oraz zasadzie bytu i życia, jest zgodne z pierwotnym porządkiem rzeczy. Taka ofiara złożona Bogu nie pada w nicość. Idol, który jest nicością, rozbija i niszczy. Dlatego ten, kto składa ofiarę idolowi, zaczyna stopniowo składać w ofierze swoje sumienie. Rodzaj eskalacji, z jaką pewni marksiści akceptują kłamstwo i zbrodnie, by służý Historii bądź Partii, to znaczy ślepym siłom, jest tragicznym potwierdzeniem tego faktu. Tym, co w ten sposób zostaje złożone w ofierze na ołtarzu Molocha, jest samo sumienie. Taki holokaust nie jest możliwy bez skrajnego gwałtu zadanego naturze ludzkiej i stanowi parodię heroizmu.

Człowiek jest wezwany do przekroczenia siebie. Może to uczynić tylko przez całkowite i ufne powierzenie się troskliwemu i ojcowskiemu Bogu, Najwyższemu i Wszechmogącemu. Jedynie ten, kto gotowy jest wszystko stracić, wszystko zyskuje. Człowiek może jednak usiłować podeptać wymagania wypisane w jego naturze przez Stwórcę. Wezwanie do doskonałości przemienia się wtedy w pełen pychy bunt przeciw niedoskonałości i przeciw ograniczeniom. Metafizyczna nienawiść w stosunku do siebie, a nie miłość Boga, sprowadza człowieka na drogę skrajności. Jak istnieje parodia heroizmu, tak jest również możliwa parodia wiary, chociaż lepiej nie mówić w tym przypadku o wierze. Wiara chrześcijańska nie jest samobójstwem rozumu, ponieważ polega na przyjęciu Słowa Bożego, czyli tego, który jest samą Prawdą i nią łaskawie obdarowuje. Nieobecność zmysłu prawdy stanowi w tym przypadku decydującą różnicę. Dlatego najśmielszy fanatyzm może wspólistnieć ze sceptycyzmem lub relatywizmem odnośnie do wartości życia, tak jak w ideologii nazistowskiej $z$ nihilizmem i beznadziejnością. Bóg, który jest światłem, jest źródłem dla tych, którzy szukają w Nim normy i wzoru postawy etycznej, w takiej mierze, w jakiej

17 Por. S. Anthonioz, „À qui me comparez-vous?”. Is 40, 25: la polémique contre l'idolâtrie dans le Deutéro-Isaie, Paris 2011. 
odbicie Jego światła powinno kształtować każdy ludzki czyn, za pośrednictwem którego człowiek zbliża się do Niego.

Idol nie rzuca żadnego światła na życie i egzystencję, jest on chmurą iluzji, która otacza ciemnością o pozorach światła. Idol prowadzi do przyjęcia jako naczelnej zasady działania: „cel uświęca środki”, to znaczy absolutyzuje je, pozostawiając nienaruszoną ich wewnętrzną perwersję w miejsce tego, co jest światłem. Idol pozwala więc na wszystko, a tym samym tyranizuje - jego bezpośrednią konsekwencją jest niemoralność. To wszystko, co jest czynione dla niego, łącznie z przestępstwem, jest „uświęcane” przez jego domniemaną sprawiedliwość. Fanatyzm, nihilizm i relatywizm moralny wynikają nawzajem $z$ siebie. Gesty i postawy skrajne nie posiadają już braków wewnętrznych, dlatego nie mogą być podważone.

\section{Zakończenie}

Idol przeciwstawia się prawdziwemu Bogu. Bałwochwalstwo - zgodnie $z$ przedstawionym wyżej opisem - rozwija się w takiej mierze, w jakiej prawda doświadcza jakiegoś schyłku, czyli traci na znaczeniu. Nie ulega wątpliwości, że świat współczesny, przez który przechodzą wielkie prądy ateistyczne, jest światem postępującego bałwochwalstwa. Eliminowanie prawdziwego Boga prowadzi w sposób bezpośredni i konieczny do pojawienia się fałszywych bogów - idoli.

Poznanie, do jakiego człowiek dochodzi w odniesieniu do Boga, rozwija się na podstawie poznania metafizycznego osiąganego w odniesieniu do stworzeń. Dlatego św. Tomasz z Akwinu nie bał się stwierdzić w sposób radykalny - może to nas zdumiewać - że jakikolwiek błąd popełniony w odniesieniu do natury stworzeń może stać się przeszkodą w dostępie do Boga i może być destrukcyjny dla samej wiary nadprzyrodzonej ${ }^{18}$. Duch ludzki, który nie wie, co oznacza przygodność rzeczy stworzonych czy też przypisuje im przymioty Boże, w punkcie wyjścia pozbawia płodności całą swoją drogę do Boga.

Takie rozważanie jest szczególnie aktualne. Rzeczywiście, chodzi o jakość świadectwa, którego oczekuje się od chrześcijan, czyli o czystość ich wiary, to znaczy, o to, by żyli zgodnie z ich godnością „dzieci światłości”. Miłość prawdy zakłada, aby być odpowiednio wrażliwym, aby podjąć właściwe działanie, na miarę swoich możliwości, aby kultywować rozumienie, jakie daje nam Bóg. Oznacza to odnalezienie zaufania do ludzkiej zdolności poznania prawdy i zmysłu powagi w przygodach ducha. W takiej mierze, w jakiej człowiek staje się sceptykiem w stosunku do zdolności metafizycznej swego rozumu, łatwo się poddaje; uważa, że rozum nie przekracza poziomu opinii, jeśli chodzi o kwestię wiary i o przedstawianie jej innym w sposób apologetyczny, to znaczy

18 Por. Tomasz z Akwinu, Summa contra gentiles II, 3. 
przekonujący. Jest to zagadnienie o zasadniczym znaczeniu dla właściwego, witalnego, osobistego usytuowanie się między „tak” i „nie”, czyli usytuowania się $\mathrm{w}$ prawdzie ${ }^{19}$.

Należy w tym miejscu podkreślić przede wszystkim rolę metafizyki i filozofii, ponieważ to najpierw w tych dziedzinach pojawiły się idole w myśli zachodniej. To zjawisko kulturowe ma konsekwencje duchowe bezpośrednie i oczywiste. Zresztą, przeciwnie do tego, co proponuje fideizm lub pesymizm reformacyjny, wiara nadprzyrodzona nie zwalnia od formacji rozumu naturalnego. Jak z jednej strony - od samego początku - potrzebujemy daru wiary, tak samo - również od początku - potrzebujemy krytycznej i inteligentnej refleksji nad podstawami wiary (praeambula fidei), aby dar Boży nie został przyćmiony przez błąd, który stanie się dla niego nieprzezwyciężalną przeszkodą. Zbyt łatwo dzisiejsi chrześcijanie dyspensują się od systematycznej refleksji nad swoją wiarą zgodnie $z$ tradycyjnym pryncypium fides quaerens intellectum. Dający się zauważyć kryzys teologii nie wróży najlepiej wierze chrześcijańskiej i Kościołowi.

Dojrzała kultura rozumu stanowi przygotowanie do odważnego i gorliwego pielgrzymowania wiary. I na odwrót, wiara sprzyja kulturze, która dzięki niej będzie mogła przyjąć, na swój własny użytek, osiągnięcia rozumu. W ten sposób dar rozumu, oczyszczając nasze spojrzenie, pomoże nam jakoś uchwycić „szerokość, długość, wysokość i głębokość” tajemnicy Boga (por. Ef 3, 18), a dar wiedzy pozwoli nam doświadczyć ułomności stworzeń. Są to jakby dwie kolumny, na których opiera się żywe odczucie prawdy. Zmysł prawdy pozwala rozumieć, że nieskończona głębia tajemnicy Boga jest źródłem i podstawą wszystkich miar - miarą wszystkich rzeczy i regułą każdego działania. Człowiek nie może żyć w pełni bez przyjęcia tej miary i bez adoracji jej pierwszego Początku. Jeśli traci z oczu, że jest stworzony „na obraz Boży”, tworzy sobie fałszywych bogów na swój obraz, ślepych, głuchych, bez dotyku, bez czucia, głupich, którymi otacza się jako zwierciadłem, które dając mu fałszywy obraz siebie, prowadzi go głupoty, czyli ostatecznie do zguby.

Słowa kluczowe: Bóg, imię Boże, bożek/idol, bałwochwalstwo/idolatria, błąd, grzech, kult, religia, pozytywizm, metafizyka, kultura.

\section{Bibliografia:}

1. Alici L., Cielo di plastica. L'eclisse dell'infinito nell'epoca delle idolatrie, Cinisello Balsamo 2009.

2. Anthonioz S., „À qui me comparez-vous?”. Is 40, 25: la polémique contre l'idolâtrie dans le Deutéro-Isaie, Paris 2011.

19 Por. W. Stróżewski, Logos, wartość, mitość, Kraków 2013, s. 325-336. 
3. Augustyn, O państwie Bożym, tł. W. Kornatowski, t. 2, Warszawa 1977.

4. Autour de l'idolâtrie. Figures actuelles de pouvoir et de domination, B. Van Meenen (red.), Bruxelles 2003.

5. Cyran W., Spoczynek w Duchu Świętym. Refleksja teologiczna i świadectwa, Częstochowa 2010.

6. Dekoninck R., Des idoles de bois aux idoles de l'esprit. Les métamorphoses de l'idolatrie dans l'imaginaire moderne, „Revue théologique de Louvain” (2004) 35, s. 203-216.

7. Grelot P., La langage symbolique dans la Bible, Paris 2001.

8. Heidegger M., Nietzsche, tł. B. Baran, t. 2, Warszawa 1999.

9. Kongregacja Nauki Wiary, List Orationis formas, [w:] W trosce o petnię wiary. Dokumenty Kongregacji Nauki Wiary. Dokumenty Kongregacji Nauki Wiary 1966-1994, J. Królikowski, Z. Zimowski (red.), Tarnów 2010, s. 407-424.

10. Leuzzi L., Allargare gli orizzonti della razionalità. I discorsi per l'Università di Benedetto XVI, Milano 2008.

11. Lidole dans l'imaginaire occidental, R. Dekoninck, M. Watthee-Delmotte (red.), Paris 2005.

12. Di Mauro A., Il problema religioso nel pensiero di Benedetto Croce, Milano 2007

13. Schleiermacher F., Mowy o religii do wyksztatconych spośród tych, którzy nia gardza, tł. J. Prokopiuk, Kraków 1995.

14. Stróżewski W., Logos, wartość, mitość, Kraków 2013.

15. Szwed A., Rozum wobec chrześcijańskiego objawienia. Kant, Hegel, Kierkegaard, Kęty 2011.

16. Tomasz z Akwinu, Summa contra gentiles. 